\title{
MACROFOSSILS AS INDICATORS OF PLIO-PLEISTOCENE CLIMATES IN TASMANIA AND ANTARCTICA
}

\author{
by R.S. Hill and G.J. Jordan
}

(with one table and five text-figures)

HiLL, R.S. \& J•R\AN, G.J., 1996 (xi): Macrofossils as indicators of Plio-Pleistocene climates in Tasmania and Antarctica. In Banks, M.R. \& Brown, M.J. (Eds): CLIMATIC SUCCESSION AND GLACIAL HISTORY OF THE SOUTHERN HEMISPHERE OVER THE LAST FIVE MILLION YEARS. Pap. Proc. R. Soc. Tasm. 130(2): 9-15. https://doi.org/10.26749/rstpp.130.2.9

ISSN 0080-4703. Department of Plant Science, University of Tasmania, GPO Box 252-80, Hobart, Tasmania, Australia 7001.

Plant macrofossils can be used as proxy palaeoclimatic indicators, since both the taxa present at a site and the form of leaves depend on the climate, and macrofossils are rarely transported far. In the simple case of the Sirius Group Nothofagus leaves and wood in Antarctica, the fossils provide data on climate that suggest temperatures at the time of deposition were in the order of $>10^{\circ} \mathrm{C}$ warmer than at present. While the age of the fossils is still debated, the climatic signal is not. However, in more subtle cases, where the climatic differences are smaller and the fossil evidence is more complex, it is critical to interpret the evidence cautiously. Macrofossils from Pleistocene localities in Tasmania provide a clear signal on temperature and rainfall that is sometimes at odds with pollen-based reconstructions, but the former is inherently likely to be more accurate.

Key Words: plant macrofossils, Tasmania, Antarctica, climatic record, Neogene, Pleistocene.

\section{INTRODUCTION}

One approach to the assessment of palaeoclimates from plant fossils is to identify the fossils as accurately as possible, and then to use the distribution and ecology of the nearest living relatives (NLRs) to assess the climate. NLR estimates of Tasmanian palaeoclimates have been both qualitative (e.g. Macphail 1979 for microfossil data; Jordan et al. 1995 for the use of combined macro- and microfossil data) and semi-quantitative (e.g. Markgraf et al. 1986), particularly using palynological data. Macrofossils in Late Pleistocene deposits can usually be ascribed to species which still live in the region under consideration. The pollen and spores can usually be ascribed to extant genera, and sometimes to species. However, the specific identity of older fossils is less certain. Thus, most Early Tertiary species are extinct, some Early Pleistocene taxa are extinct (e.g. Jordan 1992, 1995a, b, Jordan \& Hill 1994), but there are few records of extinct species in Late Pleistocene sediments (e.g. Jordan \& Hill 1991). NLR methods may be less reliable if the species is extinct, since there is considerable variation in the ecological preferences of species within living genera. This problem is partly alleviated by combining the evidence from many fossil taxa within deposits, by using broad generic climatic preferences, and by identifying taxa with anomalous climatic preferences from other sites. The NLRs of macrofossils have some advantages and disadvantages over the NLRs of pollen and spores. Macrofossils can often be identified to higher resolution than palynomorphs, but there are often stronger taphonomic biases working on macrofossils than palynomorphs.

Fossil leaves and wood can contain climatic information other than that inferred from their taxonomic affinity, because they respond directly to climate. Both the gross morphology and the anatomy of leaves appear to respond to climate. This applies both within taxa (e.g. Jordan \& Hill 1994), and also, by averaging over all the taxa or all the individual leaves, within sites (e.g. Christophel \& Greenwood 1989, Wolfe 1993, Wing \& Greenwood 1993). The models predicting climates averaging over all taxa or all leaves are quite coarse in their resolution and of little use with Plio-Pleistocene floras (G.J. Jordan, pers. obs.). The use of the variation within species may provide some refinement of NLR climatic estimates (e.g. Jordan \& Hill 1994). Similarly, wood anatomy (dendrochronological methods) can only provide coarse climate estimates when applied independent of the taxonomy, but can provide higher resolution when applied within species (Schweingruber 1988).

Well-preserved leaves and fruit of a wide range of extant and extinct species occur in a number of Pleistocene (ages follow Harland et al. 1990) sites in western Tasmania, and leaves and wood of a single species of Nothofagus occur in the probable Pliocene Sirius Group sediments in Antarctica. The present paper uses both NLR and morphological/ anatomical data to assess Pleistocene climates from Tasmania and Pliocene climate from Antarctica.

\section{SITES}

\section{Antarctica}

The fossil material occurs in the Meyer Desert Formation of the Sirius Group at Oliver Bluffs, in the Dominion Range, Transantarctic Mountains, approximately $500 \mathrm{~km}$ from the south pole and $200 \mathrm{~km}$ inland from the junction of the Beardmore Glacier and the Ross Ice Shelf. The present elevation is approximately $1760 \mathrm{~m}$ above sea level (a.s.l.), but the mountains may have been uplifted to this altitude during the past two million years (Webb \& Harwood 1993). This site is currently at $85^{\circ} \mathrm{S}$ and was at a similar latitude during the Pliocene. Plant macrofossils are preserved within several levels of the sediments, which consist of diamictites, sandstones and mudstones, interpreted to be the products of glacial, fluvial and lacustrine environments (Webb \& Harwood 1993). This glacial material was carried by ice sheets from East Antarctica and deposited along the walls of a pre-Pleistocene valley system which bisected the Transantarctic Mountains. 
The age of the sediments at Oliver Bluffs has been constrained by the presence of recycled marine diatoms in the glacial diamictites of the lower marine part of the formation. The youngest stratigraphic age of these diatoms suggests that the Sirius Group is younger than Late Pliocene in age (3.1-2.5 Ma) (Harwood 1983, 1986a, b, Webb \& Harwood 1991). Radiogenic dating of volcanic ash in cquivalent marine sediments in the CIROS-2 borehole in McMurdo Sound supports these dates (Barrett et al. 1992).

However, the dating of the sediments at Oliver Bluffs is still not clearly resolved. There have been claims that the diatoms may have been wind-blown in origin and trapped in fractures in the sediments, thus invalidating the diatom dates (e.g. Burckle \& Pokras 1991). However, Nothofagidites pollen of the same species that is known from the Sirius Group has been reported in marine sediments from Cape Adare (DSDP Site 274, Ross Sea) of mid Pliocene age, supporting the view that Nothofagus trees were present on Ancarctica at this time (Fleming \& Barron, in press).

\section{Tasmania}

The Marionoak Formation at the Huskisson/Marionoak divide ( $41^{\circ} 41^{\prime} \mathrm{S}, 145^{\circ} 31^{\prime} \mathrm{E}, 430 \mathrm{~m}$ a.s.l.) contains glacial sediments ovcrlain by fine-grained lacustrine sediments, including microfossils and some macrofossils. Palynostratigraphy implies that these sediments are likely to be Pleistocene and are no younger than the early part of the Middle Plcistocene (Macphail et al. 1993). However, these sediments are magnetically normal and underlie magnetically reversed sediments, implying that they are at least as old as the Jaramillo event in the Early Pleistocene; they are considered to be Early Pleistocene (Augustinus et al., in press).

Clasts containing well-preserved macro- and microfossils occur in Middle-Late Pleistocene gravels at Regatta Point, wescern Tasmania $\left(42^{\circ} 10^{\prime} \mathrm{S}, 145^{\circ} 20^{\prime} \mathrm{E}, 10 \mathrm{~m}\right.$ a.s.l.) (Hill \& Macphail 1985). Macphail et al. (1993) assigned an Early--?Middle Pleistocene age to a number of these clasts based on palynostratigraphy. One clast (referred to as RPU2) is palynostratigraphically at least as old as the Huskisson/ Marionoak sediments and probably older. This clast is, therefore, of Early Pleistocene age. This RPU2 clast contains three thin, intensely fossiliferous layers. The composition of each layer differs litule from the others. Other clasts (collectively referred to as RPU1 and including the clast described by Hill \& Macphail 1985) are palynostratigraphically of same age as the Huskisson/Marionoak sediments (Macphail et al. 1993) and are likely to be of Early Pleistocene age. One clast (RPA) is palynostratigraphically younger than the Huskisson/Marionoak site and is considered to be of Early-Middle Pleistocene age (Jordan et al. 1995).

The Regency Formation in western Tasmania ( $42^{\circ} 10^{\prime} \mathrm{S}$, $145^{\circ} 38^{\prime} \mathrm{E}, 180 \mathrm{~m}$ a.s.l.) consists of a $0.8 \mathrm{~m}$ thick layer of highly organic sediments, much of which is almost entirely composed of fossil leaves, fruit and twigs, and overlies an Early Pleistocene till. The formation was considered by Firzsimons et al. (1990) to be of Early-Middle Pleistocene age, but is more likely to be of Middle Pleistocene age (E.A. Colhoun, pers. comm., Jordan \& Hill 1994). The parts of the Langdon River sediments (41 $58^{\prime} \mathrm{S}, 145^{\circ} 32^{\prime} \mathrm{E}, 520 \mathrm{~m}$ a.s.l.) discussed here are highly organic sediments made up of compressed beds of leaves and twigs (Colhoun et al.
1989). These represent some Middle Pleistocene interglacial, although a Last Interglacial age cannot be excluded at present (Colhoun et al. 1989).

\section{METHODS}

Climatic estimates were made from Tasmanian Pleistocene leaf macrofossil data, using the ranges in climatic parameters of the nearest living relatives of macrofossils. For Australian taxa, climatic parameters were estimated using ESOCLIM (H. A. Nix, J.P. Busby, M.F. Hutchinson \& J.P. McMahon pers. comm.; Hutchinson 1991) analysis of a large data set of compiled poine distributions (Floyd 1990; Environmental Resources Information Network; Department of Environment and Land Management, Tasmania; Tasmanian Herbarium; Australian National Herbarium; Australian National Botanic Gardens Herbarium). Distributions for New Zealand taxa were derived from Poole \& Adams (1986), M.S. McGlone (pers. comm.) and G.J. Jordan (pers. obs.). Approximate climatic ranges for the New Zcaland taxa were then derived from local climatic averages (New Zealand Meteorological Service 1981), allowing for an altitudinal lapse rate of $0.65^{\circ} \mathrm{C} / 100 \mathrm{~m}$. Unfortunately, more detailed climatic or distriburional data was not available for New Zealand, but this does not effect the results of this work. The climatic ranges of the NLRs within sites were then compared graphically by simultaneously plotting ranges of climatic parameters of NLRs for all fossil taxa, and looking for overlaps. The region of overlap is assumed to be the best range of climatic estimates. Extreme outlier taxa were obvious and were excluded from the estimates. This method is similar to that of Kershaw \& Nix (1988) and is reasonably robust, since random subsets of the data provide essentially the same estimates (i.e. supporting the method), and the method allows for taxa to be present near the ends of their ecological range. It also allows for the identification of outlying taxa, which may represent extinct species, extinct ecotypes or taxa whose modern ranges underestimate their potential climatic ranges.

Climatic estimates for the Sirius Group were prepared using qualitative methods, which will be explained in detail in the text below.

\section{PALAEOCLIMATES}

\section{Sirius Group}

The most controversial feature of the palaeoclimate of the Sirius Group is temperature, and the macrofossils present can be used to place clear constraints on this. Three aspects of temperature will be discussed: mean annual temperature, minimum winter temperatures, and mean summer maximum temperature. In order to demonstrate how these temperatures were estimated, some features of the macrofossils must be summarised.

(1) The leaves, wood and pollen in the Sirius Group sediments all belong to a single species of Nothofagus (Nothofagaceae), the southern beech. It is reasonable to presume that it was the same species, that is, that one biological species concributed all three organs to the sediments. The leaves have been formally described as $N$. beardmorensis (Hill et $a l . .$, in press), and that name will be used for the species forthwith 
(2) Nothofagus beardmorensis was a winter deciduous species (Hill \& Truswell 1993, Hill et al., in press). This is usually difficult to prove for a fossil, but in this case the evidence is very convincing.

(3) Nothofagus beardmorensis was a ground-hugging shrub, with no main axis, but many small, twisted branches with distinct, but very small growth rings (Francis $\&$ Hill in press). There is abundant evidence for abrasion on the wood, indicative of the effect of wind-borne ice and sand particles (Francis \& Hill, in press).

(4) The macrofossils have not been transported more than a few metres from the growth position of the parent plant, and they have not been reworked. This is clear because of the thousands of delicately preserved leaves in a dense mat which could not have been reworked, and which certainly did not travel a long distance to be deposited in such dense numbers. It is also highly unlikely that leaves, wood and pollen, which have such different dispersal propetties, could occur in the same sediments in such numbers if they had been transported long distances or, indeed, if they had been reworked. This is an important point because, although there is still doubt about the age of the fossils, there can be no doubt that the plants were growing on the site when the sediments were forming, and thus are a reliable guide to the prevailing climate, whenever it was.

From a combination of these features, estimates of temperature were made.

\section{Minimum winter temperature}

There are more than 30 living species of Nothofagus, but only seven are winter deciduous, six in South America and one in Tasmania. Some research has been done to estimate the frost tolerance of these species, and this has been summarised by Hill \& Truswell (1993). Frost tolerance is likely to be a major factor limiting the distribution of a species as far as minimum winter temperatures are concerned. Direct frost damage occurs when ice crystals form within cells and lacerare the cell membranes. The damage this causes is irreversible, and the cell dies. Clearly, if this is widespread through the plant tissues, the plant will not survive. Frost damage does not necessarily occur at the same temperature in all organs and, for example, is unlikely to be relevant in the leaves of a winter deciduous species, since leaves are absent during the coldest part of the year. According to the data summarised by Hill \& Truswell (1993), the lowest frost survival temperature yet recorded for Nothofagus is $-22^{\circ} \mathrm{C}$, and this occurred in a winter deciduous species $(N$. antarctica). This is likely co be a conservative estimate, since relatively few data have been collected for extant species, and $N$. beardmorensis is likely to have had a frost resistance at the low end of the extant range and possibly well beyond it. It should also be recognised that the temperature at which ftost death occurs is not necessarily a good estimate of minimum winter temperature, since many plant species are known to be insulated againss extreme cold in winter by a thick covering of snow. That is, if $N$. beardmorensis was covered in snow during winter, then temperatures could have fallen well below its frost death temperature without the plants being subjected to them. For these reasons, the estimate of $-22^{\circ} \mathrm{C}$ for minimum winter temperature should be considered as a very conservative estimate.

Mean summer maximum temperature

A crude but very effective limit can be applied to summer temperatures -- in order fot a vascular plant to grow it must have continued access to liquid water. If air temperatures rise above freezing, but the ground stays frozen, it is possible for a plant to transpire itself to death, as it loses what liquid water it has in its tissues but cannot replace it from the frozen ground. Clearly, at the time that $N$. beardmorensis was growing, summer temperatures were sufficient to thaw soil water to some reasonable depth to allow steady transpiration. This requires temperatures well above $0^{\circ} \mathrm{C}$. Furthermore, in order to produce a crop of leaves and the reproductive structures required to produce the pollen present in the sediments, it is reasonable to assume that the daily maximum temperature must have been at least $5^{\circ} \mathrm{C}$ for several weeks. This is a conscrvative estimate based on woody plant growth requirements at high northern and southern latitudes today. It is probable that there were no particularly low minimum summer temperatures, since there is no evidence of frost damage on any of the leaf fossils.

\section{Mean annual temperature}

Francis \& Hill (in press) argued that the wood macrofossils in the Sirius Group were very similar in form and function to the wood of the extant Arctic willow (Salix arctica), although there is no close taxonomic relationship between them. In fact, this model seems very precise, and since S. arctica grows further north than any orher woody plant today, the lowest mean annual temperature at which it can grow provides a good physiological constraint on the peculiarities of wood structure observed in the fossil Nothofagus. Francis \& Hill (in press) note that this mean annual temperature is approximately $-15^{\circ} \mathrm{C}$.

Comparison with the Sirius Group today

In order to understand the significance of these temperature estimates, it is useful to have some indication of comparable temperatures at the fossil locality today. No direct measurements exist, but approximations can be made by applying a lapse rate $\left(-0.65^{\circ} \mathrm{C} / 100 \mathrm{~m}\right)$ to data from the nearest climate station. This has been done (D.M. Harwood, pers. comm.), but these estimates may contain considerable error. Neverthcless, the difference between these estimates and those from the fossils (table 1) are so great that any errors of calculation of extant temperatures must be small by

TABLE 1

Temperature data for Vanda Station* and estimates for the fossil location today ${ }^{\dagger}$

\begin{tabular}{|c|c|c|}
\hline $\begin{array}{l}\text { Vanda } \\
\text { Station }\end{array}$ & $\begin{array}{l}\text { Fossil } \\
\text { location } \\
(\text { extant })\end{array}$ & $\begin{array}{c}\text { Fossil } \\
\text { location } \\
\text { (extinct) }\end{array}$ \\
\hline \multicolumn{3}{|c|}{ Mean summer maximum temperature } \\
\hline $\begin{array}{l}+2^{\circ} \mathrm{C} \\
\text { Minimum winter temperature }\end{array}$ & $-10^{\circ} \mathrm{C}$ & $+5^{\circ} \mathrm{C}$ \\
\hline$-36^{\circ} \mathrm{C}$ & $-48^{\circ} \mathrm{C}$ & $-22^{\circ} \mathrm{C}$ \\
\hline \multicolumn{3}{|l|}{ Mean annual temperature } \\
\hline$-18^{\circ} \mathrm{C}$ & $-28^{\circ} \mathrm{C}$ & $-15^{\circ} \mathrm{C}$ \\
\hline
\end{tabular}

* 77³2'S $161^{\circ} 33^{\prime} \mathrm{E}$ near L. Vanda.

$\dagger$ Based on a lapse rate of $0.65^{\circ} \mathrm{C} / 100 \mathrm{~m}$ altitude (data provided by D. M. Harwood). Estimates for the fossil location at the time when Nothofagus beardmorensis was growing are discussed in the text. 
comparison. The differences between mean summer maximum temperature and mean annual temperature are $15^{\circ} \mathrm{C}$ and $13^{\circ} \mathrm{C}$ respectively, with the site being warmer in the past, but the close correspondence between these two figures is probably fortuitous, given the inherent errors in the method. The difference berween minimum winter temperature now and in the past at the fossil site is higher $\left(26^{\circ} \mathrm{C}\right)$, but it was stressed earlier that the estimate for the fossils was likely to be conservative, thus inflating the difference.

Therefore, as a first approximation, a temperature difference in the order of $13-15^{\circ} \mathrm{C}$ occurred between the present day and the time at which the fossil plants were growing. Other factors may enter into this; for example, the possibility of post-depositional uplift of the fossil locality (Webb \& Harwood 1993), which would artificially increase the temperature differential, although such uplift seems unlikely.

The other feature of interest in table 1 is that the difference in temperature between Vanda Station today $\left(77^{\circ} 32^{\prime} \mathrm{S}\right.$ $161^{\circ} 33^{\prime} \mathrm{E}$, near Lake Vanda and about $800 \mathrm{~km}$ from the fossil site on about the same longitude) and the requirements for the fossil species is not very great at all, being, with the exception of the conservative minimum winter temperature, only $3^{\circ} \mathrm{C}$. This is important, since it is usually considered that Antarctica is far too cold to support woody plant growth; that is not the case, and this may explain one of the dilemmas facing those arguing for the continual habitation of Antarctica by Nothofagus until the Pliocene. In fact, there is no reason for Nothofagus, in the time leading up to a Pliocene warming, not to have survived periods almost as cold as those that occur today, without recourse to unlikely long-distance dispersal of seed across prevailing winds.

\section{Tasmania}

Early Pleistocene

The macrofossil-bearing sediments at the Huskisson/ Marionoak Divide, the overlying tills and the intervening slope deposits form a sequence representing the onset of full glacial conditions of the Bulgobac Glaciation. The Bulgobac Glaciation probably occurred at the same time as the Linda Glaciation in the King River catchment (Augustinus et al., in press). This glacial probably produced the most extensive Pleistocene glaciation in Tasmania. The fossils in the Marionoak Formation, therefore, indicate conditions leading into a major Early Pleistocene glacial. Microfossils suggest that the vegetation was similar to subalpine woodland which now grows on the eastern Central Plateau of Tasmania. If correct, this indicates a rainfall in the order of 750 $1000 \mathrm{~mm}$ per annum, which is $1000-1500 \mathrm{~mm}$ below current conditions at the site (Augustinus et al., in press). This vegetation type now occurs in climates about $1-4{ }^{\circ} \mathrm{C}$ below current conditions at the site (i.e. mean annual temperatures of about $6^{\circ}-9^{\circ} \mathrm{C}$ ). The Marionoak Formation contains leaves of Orites acicularis and $O$. revoluta (Jordan 1995a), two species of Epacris/Archeria and one of Styphelieae (Jordan \& Hill, in press), and probable cyperaceous seeds. The two Orites species are subalpine-alpine species, al though their leaf form suggests that they grew in sheltered areas. The two species of Epacris/Archeria are distinct from any species now in Tasmania, but they have extremely small leaves (about 1.5-2 mm long by about $0.4 \mathrm{~mm}$ wide), and the only Tasmanian species of this group with leaves as small as this are E. navicularis, E. petrophila and extreme high-altitude forms of E. serpyllifolia. All of these are restricted to full alpine conditions. The climatic envelope implied by the macrofossils in the Marionoak Formation (fig. 1) suggests that the mean annual temperature was probably in the range of $3^{\circ}-7^{\circ} \mathrm{C}$, which is lower than the upper part of the range of the estimate from microfossils. The macrofossils provide little evidence about precipitation at this site.

The rich macrofloras in the Regatta Point sediments help elucidate several details of the climate at the time of deposition of this important fossil site, although they raise questions about some of the climatic indicator taxa. The flora has been divided into three broad groups, two of which (known as RPU2 and RPA) form discrete floras, but the third (RPUI) is an artificial composite of floras sharing a number of common features. The interpretation of the RPU2 flora is mainly based on a single layer (referred to as "17-18 cm" although it is only about 5-6 mm thick), since this undoubtedly represents a short depositional period (a few years or less) and the composition is similar to that of the other layers.

The RPU2 flora is mainly composed of elements which now occur at low altitudes in the region, but also contains a group of taxa which no longer occur in lowland western Tasmania, including apparent warm climate indicators such as macrofossils of Quintinia and Dacrycarpus (Hill \& Macphail 1985, Jordan \& Hill 1991, 1994, Jordan 1992, 1995a, b, Jordan \& Dalton, 1995). The temperature range envelopes of the macrofossils do not all overlap (fig. 2). However, all but four NLRs occur in sites with mean annual temperatures between $11^{\circ}$ and $12^{\circ} \mathrm{C}$, although this is at the extreme end of the range of several taxa. Any temperature estimate outside this range involves more discrepancies. The current mean annual temperature at Regatta Point is about $12^{\circ} \mathrm{C}$. The four taxa which do not occur at mean annual temperatures of $11^{\circ}-12^{\circ} \mathrm{C}$ are Microcachrys tetragona, Richea milliganiilacerosa, Rubus nebulosis and Callitris macleayanus. Both the Rubus and Callitris fossils are globally extinct species, and the discrepancies in temperatures are small. It is likely that these species tolerated cooler climates than their NLRs. The fossil $M$. tetragona has foliage indistinguishable from the extant species, but the distinctive pollen type is common in Tertiary deposits containing a wide range of floras, including many from

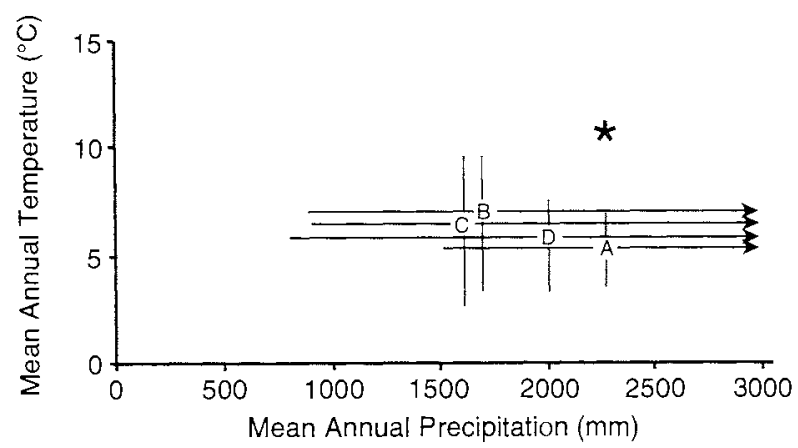

FIG. 1 - Current ranges in mean annual temperature and mean annual precipitation for the nearest living relatives (NLRs) of macrofossil seed plant taxa (A-D) found in the Early Pleistocene sediments at the Huskisson/Marionoak divide site. $A=$ Microcachrys tetragona, $B=$ Orites revoluta, $C=\mathrm{O}$. acicularis, $D=$ Epacris petrophile/navicularis. The asterisk indicates the current climate at the site. 
undoubtedly much warmer climates than the modern range of this species. It is unlikely that the macrofossils of $M$. tetragona were derived from uplands areas (Jordan \& Hill 1994; Jordan 1995b). The identification of the Richeatype fossil is relatively broad, and this may also represent an extinct species. A possible scenario to explain the apparent anomalies is that the Regatta Point sediments were deposited early in an carly interglacial, with the warm climate indicators occurring in more fertile wet forest and cool climate taxa persisting in oligotrophic areas. It is common now for subalpine type vegetation to occur in oligotrophic sites at moderate altitude alongside more typical lowland vegetation on less oligotrophic areas, particularly in areas of abundant rainfall.

There is little local topography in the Regatta Point area, and the fossiliferous clasts are highly unlikely to have been transported far, so their original site of deposition was not significantly higher than their present location. There are no micro- or macrofossils in the flora which indicate an estuarine environment. The sediments are at low altitude ( $10 \mathrm{~m}$ a.s.l.) beside an estuary, so sea level at the time of deposition was not more than about $10 \mathrm{~m}$ above present sea level. This also argues against the climate being significantly warmer than it is today. Thus, it is highly likely that the mean annual temperature at Regatta Point at the time of deposition of the RPU2 sediments was similar to the modern mean annual temperature and precipitation.

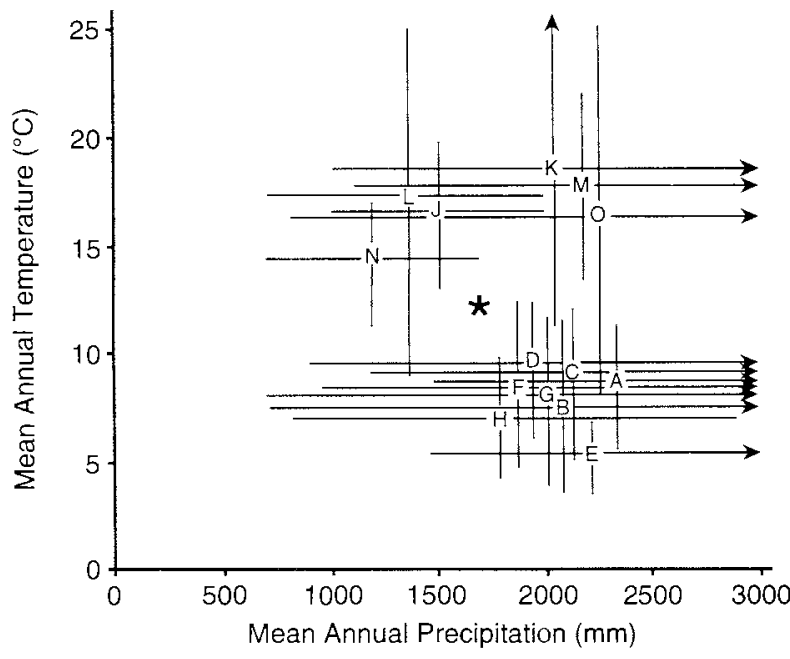

FIG. 2 - Current ranges in mean annual temperature and mean annual precipitation for the nearest living relatives (NLRS) of macrofossil seed plant taxa found in the Early Pleistocene RPU2 sediments at Regatta Point. $A=$ Agastachys odorata, $B=$ Athrotaxis spp., $C=$ Eucryphia lucida/ milliganii, Trochocarpa gunnii/cunninghamii, Orites diversifolia, $D=$ Lagarostrobos franklinii, $E=$ Microcachrys tetragona, $F=$ Nothofagus cunninghamii, $G=$ Telopea truncata, $H=$ Richea milliganii/acerosa, $J=$ Rubus nebulosus, $K=$ Lauraceae (except Cassytha), $L=$ Banksia spinulosa, $M=$ Callitris macleayanus, $N=$ Oxylobium ilicifolium, $O=$ Dacrycarpus dacrydioides and Quintinia acutifolia. The asterisk indicates the current climate at the site. Some taxa, including Acacia melanoxylon, Styphelieae, Dicksonia antarctica, Epacris spp., Pomaderris apetala and Allocasuarina, have been excluded from this plot because their climatic ranges are very broad and overlap those of several other taxa.
There is no evidence that the mean annual precipitation is any different from now, because all the precipitation of the NLRs overlap at approximately the current precipitation at Regatta Point.

The RPU1 sediments contain an assemblage of taxa which is broadly similar to that found in the RPU2 sediments, except that there are more taxa with cool climate NLRs and fewer with warm climate NLRs (Macphail et al. 1993). Thus, the fossils in these sediments are consistent with coolcr climates than the RPU2 sediments, but the evidence is not strong. Also, the RPU1 sediments are a more or less artificial assemblage of clasts, and hence climatic inferences are weak.

The RPA sediments are about $0.05 \mathrm{~m}$ thick but are likely to represent only a short period, since the matrix is coarse sand, and rapid burial under these conditions is almost certainly necessary to allow the establishment of anaerobic conditions. The macro- and microfossils in the RPA sediments have been used to suggest that the vegetation was similar to subalpine vegetation (Jordan et al. 1995). Most of the macrofossil taxa can be confidently assigned to living species. All the taxa in the sediments are consistent with Tasmanian subalpine vegetation except for spores of Cyathea, and pollen of Symplocos and Casuarinaceae (fig. 3). These taxa are considered to be outliers, whose present distributions do not indicate their past preferences. Cyathea is restricted to small lowland pockets and Casuarinaceae does not occur at high altitudes, but both Casuarinaceae and Cyathea spores are widespread and common in western Tasmanian sediments older than the last glacial maximum, even among clearly cold climate assemblages. In addition, the Allocasuarina fossils in the RPU1 and RPU2 sediments are of an extinct species. The Huskisson/Marionoak Divide flora also contains Symplocos pollen, which suggests that this pollen type in the RPU1, RPU2 and RPA sediments was produced by a species which grew outside the modern climate range of the genus. The climatic envelopes (fig. 1) indicate that the temperature was most likely to be within the range of $5^{\circ}-8^{\circ} \mathrm{C}$, and thus $4^{\circ}-7^{\circ} \mathrm{C}$ cooler than at present. The climatic envelopes suggest that the precipitation was probably more than about $1200 \mathrm{~mm}$ per annum (fig. 1) and, thus, little, if at all, drier than at present.

\section{Middle Pleistocene}

There are significant changes in the composition of both macro- and microfossil assemblages through the Regency Formation (Fitzsimons etal. 1990). This has been interpreted as most likely showing a change in vegetation from cooler climates into full interglacial conditions, with probably a similar climate to that at present, although these changes may be the result of successional change (Fitzsimons et al. 1990). The climatic ranges of the NLRs of macrofossil taxa occurring in the lower part of the Formation (Zone RY1 of Fitzsimons et al. 1990) all overlap in the range of mean annual temperature $8.1-11.4^{\circ} \mathrm{C}$ (fig. 4). In the upper section (Zone RY2) the overlap is in the range of $6.1-11.6^{\circ} \mathrm{C}$ (fig. 5). Therefore, the climatic ranges of the NLRs of all the macrofossils throughout the sediments are consistent with modern temperatures. The climatic ranges of the NLRs of all the microfossil taxa in the sediments (Fitzsimons et al. 1990), except Nothofagus gunnii and Microcachrys tetragona, also overlap with the modern climate, and both $N$. gunnii and $M$. tetragona occur as rare grains both above and below the supposed climate change in the Regency sediments. Thus, the palaeobotanical evidence for climatic change in 


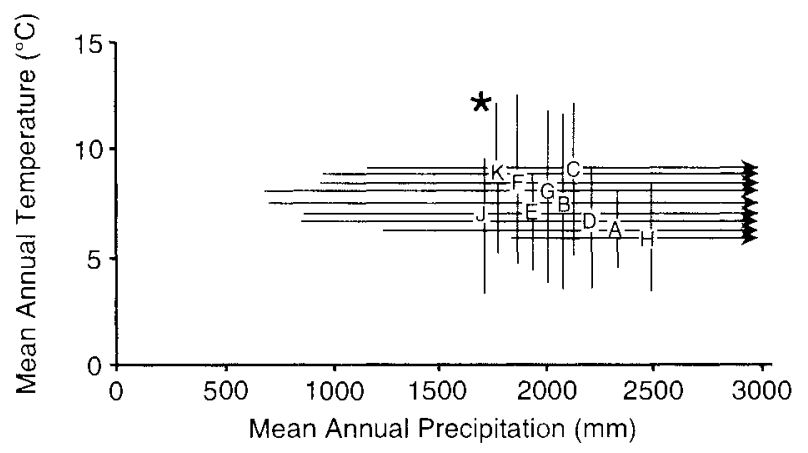

FIG. 3 - Current ranges in mean annual temperature and mean annual precipitation for the nearest living relatives (NLRs) of macrofossil seed plant taxa ( $A-J$ ) found in the Early-Middle Pleistocene RPA sediments at Regatta Point. $A=$ Athrotaxis cupressoides, $B=$ Athrotaxis selaginoides, $C=$ Eucryphia lucida/milliganii $D=$ Diselma archerii, $E=$ Nothofagus gunnii, $F=$ Nothofagus cunninghamii, $G=$ Telopea runcata, $H=$ Orites milliganii, $J=$ Orites revoluta, $K=$ Phyllocladus aspleniifolius. The asterisk indicates the current climate at the site.

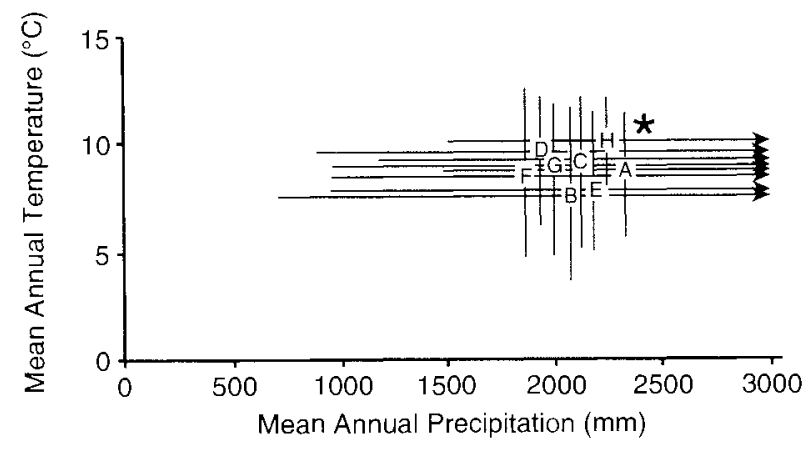

FIG. 4 - Current ranges in mean annual temperature and mean annual precipitation for the nearest living relatives (NLRS) of macrofossil seed plant taxa found in the lower section (Zone RY1 of Fitzsimons et al. 1990) of the Middle Pleistocene Regency Formation. $A$ = Agastachys odorata, $B=$ Athrotaxis selaginoides, $C=$ Trochocarpa gunnii/ cunninghamii, $D=$ Lagarostrobos franklinii, $E=$ Eucryphia lucida, $F=$ Nothofagus cunninghamii, Cenarrhenes nitida, $G=$ Phyllocladus aspleniifolius, $H=$ Allocasuarina zephyrea. The asterisk indicates the current climate at the site.

this site is weak and is based on changes in the abundance of taxa. The change in composition of the flora could easily be explained by vegetacion succession, or possibly by changes in the depositional environment.

Discussion of Tasmanian Pleistocene data

There is no convincing macrofossil or microfossil evidence of climates warmer than now in the Pleistocene in Tasmania. The best estimates of temperature for all sites are the same as, or lower than present climates. The fossils at the Early Pleistocene RPU2 sediments and the Middle Pleistocene Regency Formation are consistent with climates as warm as those which now prevail. There are orher Middle and Late Pleistocene sites containing macrofossils, including the

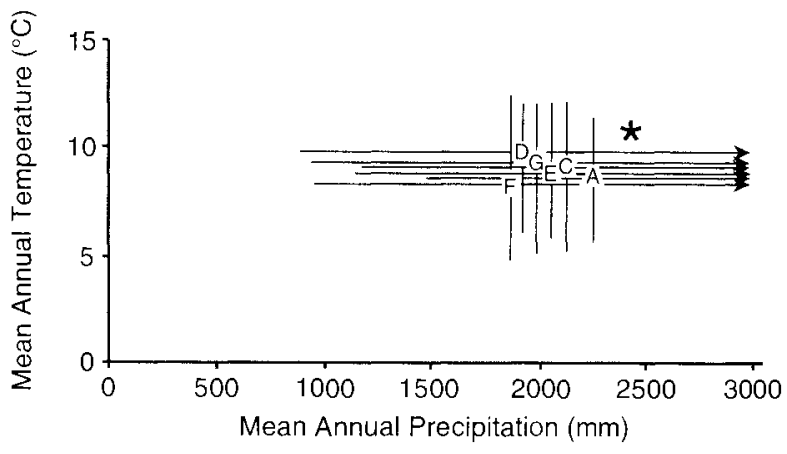

FIG. 5 - Current ranges in mean annual temperature and mean annual precipitation for the nearest living relatives (NLRS) of macrofossil seed plant taxa found in the upper section (Zone RY2 of Fitzsimons et al. 1990) of the Middle Pleistocene Regency Formation. $A=$ Agastachys odorata, $C=$ Trochocarpa gunnii/cunninghamii $D=$ Lagarostrobos franklinii, $E=$ Eucryphia lucida, $F=$ Nothofagus cunninghamii, $G=$ Phyllocladus aspleniifolius. The asterisk indicates the current climate at the site.

Langdon River site (Colhoun et al. 1989) and Melaleuca Inlet (Jordan et al. 1991), which, based on similar arguments, are consistent with temperatures similar to modern temperatures. There are constraints on the upper estimates of climates for lowland sites younger than the Early Pleistocene, since virtually all the taxa involved are still extant in Tasmania and, hence, their climatic ranges include Tasmanian climates. However, it is also clear that many taxa previously used as war m climate indicators probably occurred in cooler climates than their NLRs, and their presence cannot be used as good evidence of warm climates. There is convincing evidence of colder climates than at present at times in the Early-Middle Pleistocene $\left(1-4^{\circ} \mathrm{C}\right.$ colder at the Huskisson/Marionoak Divide site and $4-7^{\circ} \mathrm{C}$ colder in the RPA sediments).

\section{ACKNOWLEDGEMENTS}

This research was funded by the Australian Research Council via a large grant to R. S. Hill and a fellowship to G. J. Jordan.

\section{REFERENCES}

Augustinus, P.C., Macphall, M.K. \& Pollington, M.J., in press: Early Pleistocene stratigraphy and timing of the Bulgobac Glaciation, western Tasmania, Australia. Palaeogeogr. Palaeoclimatol. Palaeoecol.

Barrett, P.J., Adams, C.J., McIntosh, W.C., Swisher III, C.C. \& WILSON, G.S., 1992: Geochronological evidence supporring Antarctic deglaciation three million years ago. Nature 359: 816-818.

BURCKLE, L.H. \& POKRAS, E.M., 1991: Implications of a Pliocene stand of Nothofagus (southern beech) within 500 kilomerres of the South Pole. Antarct. Sci. 3: 389-403.

Christophel, D.C. \& Greenwood, D.G., 1989: Changes in climate and vegetation in Australia during the Tertiary. Rev. Palaeobot. Palynol. 58: 95-109.

Colhoun, E.A., van der Geer, G., Hill, R.S. \& Bird, T., 1989: Interglacial pollen and plant macrofossils from Langdon River, western Tasmania. New Phytol. 111: 531-548. 
Fitzsimons, S.J., Colhoun, E.A., van der Geer, G. \& Hill, R.S., 1990: Definition and character of the Regency Interglacial and Early-Middle Pleistocene stratigraphy in the King Valley, western Tasmania, Australia. Boreas 19: $1-15$.

Fleming, R.F. \& BARRon, J.A., in press: Evidence of Pliocene Nothofagus in Antarctica from Pliocene marine sedimentary deposits (DSP Site 274). Mar. Micropalaeontol.

FLOYD, A.G., 1990: AUSTRALIAN RAINFORESTS IN NEW SOUTH WALES. VOL. II. Surrey Beattie and Sons, Chipping Norton, Australia.

Fruncis, J.E. \& HiLl, R.S., in press: Pliocene fossil plants from the 'Transantarctic Mountains: Evidence for climate from growth rings and fossil leaves. Palaios.

Harland, W.B., Armstrong, R.L., Cox, A.V., Craig, L.E., SMITH, A.G. \& SMITH, D.G., 1990: A GEOLOGIC TIME SCALE 1989. Cambridge University Press: New York.

HARWOOD, D.M., 1983: Diatoms from the Sirius Formation, Transantarctic Mountains. Antarct. J. U.S. 18: 98-100.

Harwood, D.M., 1986a: Diatom biostratigraphy and paleoecology and Cenozoic history of Antarctic ice sheets. Unpubl. PhD thesis, Ohio State Univ., Ohio.

HARWOOD, D.M., 1986b: Recycled siliceous microfossils from the Sirius Formation. Antarct. J. U.S. 21: 101-103.

Hill, R.S. \& Macphiall, M.K., 1985: A fossil flora from rafted Plio-Pleistocene mudsrones at Regatta Point, Tasmania. Aust. J. Bot. 33: 497-517.

Hill, R.S. \& Truswell, E.M., 1993: Nothofagus fossils in the Sirius Group, Transantarctic Mountains: leaves and pollen and their climatic significance. In The Antarctic Paleoenvironment: A Perspective on Global Change. Antarct. Res. Ser. 60: 67-73.

Hill, R.S., Harwood, D.M. \& Webb, P.-N., in press: Nothofagus beardmorensis (Nothofagaceae), a new species based on leaves from the Pliocene Sirius Group, Transantarctic Mountains, Antarctica. Rev. Palaeobot. Palynol.

Hutchinson, M.F., 1991: The application of thin-plate smoorhing splines to continent-wide data assimilation. BMRC Res. Rep. 27. Bureau of Meteorology, Melbourne: 104 113.

Jordan, G.J., 1992: Macrofossil evidence for Quaternary plant extinction and vegecation change in western Tasmania. Unpubl. PhD thesis, Univ. Tasm., Hobart.

Jordan, G.J., 1995a: Early-Middle Pleistocene leaves of extinct and extant Proteaceae from western Tasmania, Australia. Bot. J. Linn. Soc. 118: 19-35.

JORDAN, G.J., 1995b: Extinct conifers and conifer diversity in the Early Pleistocene of western Tasmania. Reu. Palaeobot. Palynol. 84: 375-387.

Jordan, G.J. \& DalTon, P.J., 1995: Mosses from Early Pleistocene sediments in western Tasmania. Alcheringa 19: $291-$ 296.

Jordañ, G.J. \& Hill, R.S., 1991: Two new Banksia species from Pleistocene sediments in Western Tasmania. Aust. Syst. Bot. 4: 499-511.
JORDAN, G.J. \& HiLL, R.S., 1994: Past and present variability in leaf length of evergreen members of Nothofagus subgenus Lophozonia related to ecology and populations dynamics. New Phytol. 127: 377-390.

Jordan, G.J. \& HiLl, R.S., in press: The fossil record of the Epacridaceae. Annals of Botany.

Jordan, G.J., Carpenter, R.J. \& Hill, R.S., 1991: Late Pleistocene vegetation and climate near Melaleuca Inlet, south-west Tasmania, as inferred from fossil evidence. Aust. J. Bot. 39: 315-333.

Jordan, G.J., Macphall, M.K., Barnes, R. \& Hill, R.S., 1995 An Early-Middle Pleistocene flora of subalpine affinities in lowland western Tasmania. Aust. J. Bot. 43: 231-242.

KersHAW, A.P. \& NIX, H.A., 1988: Quantitative palacoclimatic estimates from pollen data using bioclimatic profiles of extant taxa. J. Biogeogr. 15: 589-602.

Macphal, M.K., 1979: Vegetation and climates in southern Tasmania since the Last Glaciation. Quat. Res. 11, 306341.

Macphail, M.K., Jordan, G.J. \& Hill, R.S., 1993: Key periods in the evolution of the flora and vegetation in western Tasmania I. The Early-Middle Pleistocene. Aust. J. Bot. 41: 673-707.

Markgraf, V., Bradbury, J.P. \& Busby, J.B., 1986: Paleoclimates in southwestern Tasmania during the last 13,000 years. Palaios 1: 368-380.

New Zenland Meteorological Service, 198 I: Summaries of climatological observations to 1980. N. Z. Meteorol. Serv. Misc. Publ.

POOLE, A. L. \& ADAMS, N. M., 1986: TREES AND SHRUBS OF NEW ZEALAND. Government Printing Office, Wellington.

SCHWEINGRUBER, F.H., 1988: TREE RINGS: BASICS AND APPLICATIONS OF DENDROCHRONOLOGY. Kluwer Academic Publications, Dordrecht, The Netherlands.

Webb, P.-N. \& Harwood, D.M., 1991: Late Cenozoic glacial history of the Ross Embayment, Antarctica. In Cronin, T. \& Dowsett, H. (Eds): Pliocene Climates. Quat. Sci. Rev. 10: 215-223.

Webb, P.-N. \& HArwood, D.M., 1993: Pliocene fossil Nothofagus (Southern Beech) from Antarctica: phytogeography, dispersal strategies, and survival in high-latirude glacialdeglacial environments. In Alden, J. et al. (Eds): FOREST DEVELOPMENT IN COLD CLIMATES. Plenum Press, New York: 135-163.

WiNG, S.L. \& GREENWOOD, D.R., 1993: Fossils and fossil climate: the case for equable continental interiors in the Eocene. Phil. Trans. R. Soc. London, Ser. B 341: 243-252.

WOLFE, J.A., 1993: A method of obtaining climatic parameters from leaf assemblages. Bull. U.S. Geol. Surv. 2040.

(accepted 14 May 1996) 